\title{
Performance of Phonological Processing in Children with Attention Deficit Hiperactivity Disorder
}

\author{
Talita Fernanda Gonçalves-Guedim*, Patrícia Abreu Pinheiro Crenitte \\ Department of Speech-Language Pathologists, Faculty of Dentistry of Bauru, University of São Paulo \\ (USP), Bauru, Brazil \\ Email: ${ }^{\text {talita fg@hotmail.com }}$
}

Received 2 December 2013; accepted 17 August 2015; published 20 August 2015

Copyright (C) 2015 by authors and Scientific Research Publishing Inc.

This work is licensed under the Creative Commons Attribution International License (CC BY). http://creativecommons.org/licenses/by/4.0/

c) (i) Open Access

\begin{abstract}
Purpose: The objective of this study was to compare the performance of Phonological Processing (Phonological Awareness, Lexical Acess and Working Memory) between children with ADHD and children with typical development. Methods: Participated in this study, 30 school aged children of both genders aged between 9 - 12 years, divided into 2 groups: Experimental Group (EG), 15 children with ADHD combined type and, Control Group (CG), 15 children with typical development, who attended elementary school in public and private education. The instruments utilized were: Phonological Awareness Test-Sequential Assessment Tool (CONFIAS); Rapid automatic Naming Testd); and Proof of repetition of nonsense words (Kessler, 1997). Results: The results revealed differences between in the instruments used. Conclusion: Regarding the performance of Phonological Processing, the children with ADHD showed lower performance in Phonological Awareness, Access to Lexical and Phonological Memory compared to children with typical development.
\end{abstract}

\section{Keywords}

Children, Evaluation, Learning, Reading, Writing

\section{Introduction}

The Attention Deficit Hyperactivity Disorder (ADHD) is a common neuropsychiatric disorder of childhood (Casella, 2009) and is present among most students (American Academy of Pediatrics, 2000). In samples not referenced, it is estimated that $3 \%$ to $6 \%$ of school-aged children have ADHD (Benczik \& Rodhe, 1999; Faraone,

${ }^{*}$ Corresponding author.

How to cite this paper: Gonçalves-Guedim, T. F., \& Crenitte, P. A. P. (2015). Performance of Phonological Processing in Children with Attention Deficit Hiperactivity Disorder. Psychology, 6, 1331-1339.

http://dx.doi.org/10.4236/psych.2015.610130 
2003). ADHD is often manifested early in the life of the individual, but only outset the scholarity that the symptoms become perceptible, suggesting the diagnosis (Diniz Neto \& Sena, 2007; Zorzi \& Ciasca, 2009; Pinheiro, Lourenceti, \& Santos, 2010; Silva, Cunha, \& Capellini, 2011), and may present failure in their academic performance, determined by changes in the input information. The attention difficulties and hyperactivity displayed by children with ADHD can affect their academic performance. In addition to the symptoms of the disorder, over 50\% of cases there are comorbidities (Mattos et al., 2006; Gomes et al., 2007). Individuals with ADHD often have comorbid language impairment (Boada, Willcutt, \& Pennington, 2012). The language deficit displayed may affect learning the alphabetic writing system, considering the skills that underlie this process, such as metalinguistic skills (ability to reflect on language), that may impair the acquisition. And the inattentive behavior determines basic difficulties in perception and processing of visual and auditory information, which is fundamental in the learning process (Miranda, Garcia, \& Jara, 2001; Rabiner \& Malone, 2004; Asberg, Dahlgren, \& Sandberg, 2008; Ygual-Fernández et al., 2011).

Phonological Processing (PP) skills are essential for the acquisition and development of reading and writing (Pestun, 2005). PP refers to phonological information received through hearing, which is directly related to the development of oral and written language as a system of alphabetic writing (Wagner \& Torgesen, 1987). The Phonological Awareness (PA), Lexical Access (LA) and Working Memory (WM) compose the PP.

The PA may be defined as an ability to manipulate the structure of noise words from the replacement of a particular sound to the segmentation of smaller units. The PA is an important factor in the development of reading and writing (Walcott, Scheemaker, \& Bielski, 2010; Cunha \& Capellini, 2011). It is in the beginning of scholarity that children learn to read and write, developing the ability to pay attention to speech, observing the various segments, phonemes, syllables and words (Maluf \& Barreira, 1997). Studies show the relationship between deficits in PA and difficulties in writing, pointing out that children who do not have this ability are subject to fail to learn to read and write (Capellini \& Ciasca, 2000; Crenitte, 2002; Santamaria, Leitão, \& Assencio-Ferreira, 2004).

The LA is understood as part of the speed of information processing (Wagner \& Torgesen, 1987). Studies claim that the AL is associated with reading, especially in decoding skills, fluency and comprehension (Wagner et al., 1997; Wolf \& Bowers, 1999; Brizzolara et al., 2006; Vukovic \& Siegel, 2006; Miranda-Casas et al., 2010).

The WM is responsible for the temporary storage of information while performing cognitive tasks such as reasoning, comprehension and learning (Alloway, Gathercole, \& Elliott, 2010; Carrilo-Mora, 2010; Voorde, Roeyers, \& Wiersema, 2010, Ferreira, Valentin, \& Ciasca, 2013). According to the model of Baddeley and Hitch (1974) and Barkley (2002), the WM is responsible for maintaining the information recently processed and the establishment of connections with the new information. WM is the basis of learning and when altered, can cause damage and learning disabilities (Martinussen, 2005).

Studies have shown that individuals with ADHD often have a deficit of WM, which may be identified through evaluations, which have underperformed when compared to individuals without ADHD, thus impairing the performance of the learning of reading and writing (Wechsler, 1993; Shue \& Douglas, 1992). This suggests that deficiencies in MT are associated with low learning outcomes and are a high risk factor for failure in school for children (Alloway, Gathercole, \& Elliott, 2010).

Given the above, the objective of this study was to compare the performance of Phonological Processing (Phonological Awareness, Lexical Acess and Working Memory) between children with ADHD and children with typical development.

\section{Method}

\subsection{Subjects}

The study was approved by the Research Ethics Committee with Humans, Faculty of Dentistry of Bauru-USP, process n. 65/2010.

Participating in this study were 30 school aged children of both genders (24\% - 80\% male children and 6\% 20\% female children), aged between 9 - 12 years, divided into 2 groups: Experimental Group (EG), 15 children with ADHD combined type and, Control Group (CG) 15 children with typical development, who attended elementary school in public and private education. The EG was matched to the CG according to chronological age, gender and type of institution (public or private) education. 
The inclusion criterion for the CG was: children diagnosed with ADHD combined, based on the diagnostic criteria of the DSM-IV TR (APA, 2002) with complaints of difficulties in reading and writing. During phonoaudiological evaluation the students were without drug action. The inclusion criterion for the CG was: to present typical development and good academic performance, according to school information and evaluation criteria of the researcher. For both groups the inclusion criterion was: intellectual performance within the normal ranges observed for psychological evaluation by psychologists belonging to an interdisciplinary team of both institutions; normal development of hearing and speech; visual acuity.

\subsection{Instruments}

a) Anamnesis Guide: specifies interview with the responsible, referring to the development and learning of the students participating in this study.

b) Phonological Awareness Test-Sequential Assessment Tool (CONFIAS) (Moojen et al., 2003). This exam consists of two parts, the first corresponding to the syllabic awareness and the second part representing the phonemes awareness. The application followed the proposal to begin the sequential tasks involving syllable awareness and, subsequently, those relating to the phoneme level, respecting their order. For this study, only the results of the syllable, phoneme and total were used. The scoring of the test was carried out in a specific protocol. The correct answers are worth one point and the wrong cards are worth zero. In the syllable, the maximum score is 40 and in the phoneme part the maximum score is 30 , totaling 70 points, which is $100 \%$ correct.

c) Rapid automatic Naming Test: computerized version of the Rapid Serial Naming Test (Denckla \& Rudel, 1974; Ferreira et al., 2003) is composed of the subtests of naming colors, digits, letters and objects. The subtests consist of five different stimuli, which alternate with each other, forming ten sequential lines for a total of fifty stimuli. Before beginning the test, the children were instructed to repeat the stimuli presented, with the fastest speed possible and without errors, to measure the reaction time. The scores were expressed in time (seconds).

d) Proof of repetition of nonsense words (Kessler, 1997): was applied to a list of 30 nonsense words in Portuguese, organized into six sublists, each with five nonsense words that vary according to the number of syllables from one to six, consisting of simple syllable structure, privileging the consonant-vowel and consonant-vowelconsonant. To analyze the results, the number of words repeated correctly was counted.

\subsection{Procedures}

Data collection was realized individually in both groups. To evaluate the GC, the researcher contacted public and private schools, according to the type of school that the participant attended GE, considering the criteria of matching. In order to not interfere in the children's performance in school, the evaluation took place outside of school hours at the school. The selected students were nominated by the teacher, appointed by good academic performance and those responsible for anamnesis. The number of sessions varied depending on the individual characteristics and requirements. Complete reviews lasted two to three sessions, with varying lengths, according to the disposition of each participant.

The data was submitted to descriptive and inferential statistical analysis by the Student Test and nonparametric Mann-Whitney Test. The adopted significance level is $5 \%(0.05)$ for the statistical tests, ie, when the calculated significance value $(p)$ is less than $5 \%(0.05)$, there was a difference "statistically significant". Statistically significant results were marked by an asterisk $(*)$.

\section{Results}

\section{Performance of GE relative to GC in the proof of Phonological Awareness}

In the PA test, it was observed that the students from EG had a lower GC performance, phonemic and syllable subtest, significance was found between groups by means of the t Student test (Table 1).

\section{Performance of GE relative to GC in the proof of Rapid automatic Naming}

To compare the performance of students in the ability to access the lexicon, we used the t Student Test. Met significance in the test of lexical access of letters and digits (Table 2).

\section{Performance of GE relative to GC in the proof of Working Memory}

Data analysis of WM used the nonparametric Mann-Whitney Test, in order to compare the performance 
Table 1. Performance comparison among experimental and control groups in the proof of phonological awareness.

\begin{tabular}{ccccc}
\hline Variables & Group & Mean & Standard Deviation & Significance $(\boldsymbol{p})$ \\
\hline \multirow{2}{*}{ PA Syl. } & EG & 29.47 & 5.87 & $0.00^{*}$ \\
& CG & 37.53 & 1.30 & $0.00^{*}$ \\
PA Phon. & EG & 17.47 & 6.61 & $0.00^{*}$ \\
\hline
\end{tabular}

Legend: PA Syl: Phonological Awareness Syllable; PA Phon: Phonological Awareness Phonemic; t de Student Test. *Significant.

Table 2. Performance comparison among experimental and control groups in the proof of lexical access.

\begin{tabular}{ccccc}
\hline Variables & Group & Mean & Standard Deviation & Significance $(\boldsymbol{p})$ \\
\hline \multirow{2}{*}{ LA Colors } & EG & 51.16 & 16.43 & 0.09 \\
& CG & 42.44 & 11.01 & $0.00^{*}$ \\
\multirow{2}{*}{ LA Letters } & EG & 41.74 & 14.30 & $0.00^{*}$ \\
& CG & 25.13 & 4.43 & 0.57 \\
\hline
\end{tabular}

Legend: LA Colors: Lexical Acess Colors; LA Letters: Lexical Acess Letters; LA Digits: Lexical Acess Digits; LA Object: Lexical Acess Object. t de Student Test. *Significant.

among the groups (Table 3). As seen in Table 3, it was possible to verify that the students from EG showed a lower performance than CG, with statistically significant difference.

\section{Discussion}

ADHD affects the way the child adapts in the academic environment, in interpersonal relationships and in school performance which interferes in the learning process. The PP has been the subject of numerous studies (Ygual-Fernández, Miranda-Casas, \& Cervera-Mérida, 2000; Mulas et al., 2006; Capovilla, Dias, \& Montiel, 2007; Freitas, Cardoso, \& Siquara, 2012), being recognized as a component that participates in the development process of reading and writing. As shown in studies (Bedmarek, Saldaña, \& García, 2009; Pinheiro, Germano, \& Capellini, 2010; Piasta \& Wagner, 2010; Villagrán et al., 2010), changes in phonological processing skills, PA, LA and WM, hamper the development of reading and writing. They are important for the development of reading skills and these changes are found in children with learning problems.

According to the results obtained in this study we found that the performance of GE, was statistically inferior to the performance of the GC, the skills of Phonological Processing.

Individuals with ADHD have alterations in reading and writing because of deficits in PA and WM (Lobo \& Lima, 2008; Nunes, Frota, \& Mousinho, 2009; Germano, Pinheiro, \& Capellini, 2009; Voorde et al., 2009; Silva \& Capellini, 2010).

The PA has a reciprocal relationship with the development of reading and writing. For the development of PA, it is also necessary the relationship between WM and performance in activities (Gindri, Keske-Soares, \& Mota, 2007; Oliveira et al., 2011). According to the results obtained in the PA test, students with ADHD had this ability underperformed when compared to GC, especially when it comes to the concept of phonemes, with no significant difference (Table 1). The result of this study corroborates with Capellini and Lanza (2011), which also found lower performance in the ability of CF compared with typically developing individuals, ie, without reading and writing.

Several studies affirm this result, stating that children with ADHD have deficits in the learning of metalinguistic skills and phonological aspects of language, affecting acquisitions, such as reading and writing (Ygual-Fernández, Miranda-Casas, \& Cerveramérida, 2000; Gallardo-Paúls \& Martinéz, 2010; Campos, 2010; Oliveira et al., 2011). 
Table 3. Performance comparison among experimental and control groups in the proof of working memory.

\begin{tabular}{ccccc}
\hline Variables & Group & Mean & Standard Deviation & Significance $(\boldsymbol{p})$ \\
\hline \multirow{2}{*}{ WM } & EG & 3.73 & 0.80 & $0.00^{*}$ \\
\hline
\end{tabular}

Legenda: WM: Working Memory. Mann Whitney Test; "Significant.

Attention and concentration is needed to perform CF tasks (Asberg, Dahlgren, \& Sandberg, 2008; Chard et al., 2008; Cunha \& Capellini, 2009). This data suggests that the performance of this skill can be altered due to the characteristics of the diagnosis itself, in which children with ADHD have hyperactivity and attentional changes, interfering with retention of information (Mulas et al., 2006; Cavadas, Pereira, \& Mattos, 2007).

In recent decades, one of the skills studied further was Lexical Access (Capellini et al., 2007). Through research, it was possible to define normal ranges for different types of tasks Rapid automatic Naming (Denckla \& Rudel, 1974).

The results presented in this study showing evidence of naming letters and digits, were statistically significant, since the proofs of colors and objects were not significant among the groups (Table 2). Students with ADHD are slow to name them, with lower scores than the CG. Thus, it was revealed that children with ADHD had less than the Control Group in the Rapid automatic Naming performance, as also shown in the study by Van Mourik, Oosterlaan, Sergeant (2005).

In this perspective, the present study confirms the findings from Capellini et al. (2007), in which children with ADHD are impaired in Rapid Automatic Naming, struggling to quickly appoint stimuli such as colors, digits, letters and objects. González (2004), Capellini and Conrad (2009) and Bicalho and Alves (2010) emphasize that individuals with learning disabilities performed worse in activities that require speed of processing visual information. Studies show that individuals who exhibit attentional failures possibly have low performance in naming stimuli, and consequently, changes in reading fluency (Tannock, Banaschewski, \& Gold, 2006; Pham, Fine, \& Semrud-Clikeman, 2011).

The WM refers to the ability to temporarily retain and manipulate information. Difficulties of Working Memory largely affect information processing, since the memory is a mediating structure of information.

The students of GE in this study had a lower GC performance of MT results, as shown in Table 3. Results affirm Messina and Tiedemann (2009), Sowerby, Seal \& Tripp (2011) and Bolden et al. studies (2012), who reported that children with ADHD have greater inattention and this would probably be one of the causes of low capacity in MT. In studies Schweitzer et al. (2000), Andrade (2002), Oliveira (2007) and Rapport et al. (2008), individuals with ADHD also showed lower performance than expected, also affirming the results found in this study.

\section{Conclusion}

Regarding the performance of Phonological Processing, the children with ADHD showed lower performance in Phonological Awareness, Access to Lexical and Phonological Memory compared to children with typical development.

\section{Financial Support}

Fundação de Amparo à Pesquisa do Estado de São Paulo (FAPESP).

\section{References}

Alloway, T. P., Gathercole, S. E., \& Elliott, J. (2010). Examining the Link between Working Memory Behaviour and Academic Attainment in Children with ADHD. Developmental Medicine \& Child Neurology, 52, 632-636. http://dx.doi.org/10.1111/j.1469-8749.2009.03603.x

American Academy of Pediatrics (2000). Clinical Practice Guideline: Diagnosis and Evaluation of the Child with Attentiondefict/Hyperactivity Disorder. Pediatrics, 105, 1158-1170. http://dx.doi.org/10.1542/peds.105.5.1158

Andrade, E. R. (2002). Memória de trabalho verbal e visual em crianças com Transtorno do Déficit de Atenção/Hiperatividade. Ph.M. Thesis, São Paulo: Universidade de São Paulo.

APA (American Psychiatric Association) (2002). Manual estatístico de transtornos mentais. (DSM-IV TR). Porto Alegre: 
Artmed.

Asberg, J., Dahlgren, S., \& Sandberg, A. D. (2008). Basic Reading Skills in High-Functioning Swedish Children with Autism Spectrum Disorders or Attention Disorder. Research in Autism Spectrum Disorders, 2, 95-109. http://dx.doi.org/10.1016/j.rasd.2007.03.006

Baddeley, A. D., \& Hitch, G. (1974). Working Memory. In: G. H. Bower (Ed.), The Psychology of Learning and Motivation (pp. 47-90). Londres: Academic Press. http://dx.doi.org/10.1016/s0079-7421(08)60452-1

Barkley, R. A. (2002). Transtorno de Déficit de Atenção/Hiperatividade (TDAH): Guia completo para pais, professores e profissionais da saúde (p. 238). Porto Alegre: Artmed.

Bedmarek, D., Saldaña, D., \& Garcia, I. (2009). Visual versus Phonological Abilities in Spanish Dyslexic Boys and Girls. Brain and Cognition, 70, 273-278. http://dx.doi.org/10.1016/j.bandc.2009.02.010

Benczik, E. B. P., \& Rodhe, L. A. P. (1999). Transtorno de Déficit de Atenção/ Hiperatividade: O que é? Como ajudar? Porto Alegre: Artes Médicas Sul.

Bicalho, L. G. R., \& Alves, L. M. A. (2010). Nomeação seriada rápida em escolares com e sem queixas de problemas e aprendizagem em escola pública e particular. Revista CEFAC, 12. http://dx.doi.org/10.1590/S1516-18462010005000018

Boada, R., Willcutt, E. G., \& Pennington, B. F. (2012). Understanding the Comorbidity between Dyslexia and AttentionDeficit/Hyperactivity Disorder. Topics in Language Disorders, 32, 264-284. http://dx.doi.org/10.1097/TLD.0b013e31826203ac

Bolden, J. et al. (2012). Understanding Phonological Memory Deficits in Boys with Attention-Deficit/Hyperactivity Disorder (ADHD): Dissociation of Short-Term Storage and Articulatory Rehearsal Processes. Journal of Abnormal Child Psychology, 40, 999-1011. http://dx.doi.org/10.1007/s10802-012-9619-6

Brizzolara, D. et al. (2006). Do Phonologic and Rapid Automatized Naming Deficits Differentially Affect Dyslexic Children with and without a History of Language Delay? A Study of Italian Dyslexic Children. Cognitive \& Behavioral Neurology, 19, 141-149. http://dx.doi.org/10.1097/01.wnn.0000213902.59827.19

Capellini, S. A. et al. (2007). Desempenho de escolares bons leitores, com dislexia e com Transtorno do Déficit de Atenção e Hiperatividade em Nomeação Automática Rápida. Revista da Sociedade Brasileira de Fonoaudiologia, 12, 114-119. http://dx.doi.org/10.1590/S1516-80342007000200008

Capellini, S. A., \& Ciasca, S. M. (2000). Avaliação da Consciência Fonológica em crianças com distúrbio específico de leitura e escrita e distúrbio de aprendizagem. Temas sobre Desenvolvimento, 8, 17-23.

Capellini, S. A., \& Conrado, T. L. B. (2009). Desempenho de escolares com e sem dificuldades de aprendizagem de ensino particular em habilidade fonológica, Nomeação Rápida, leitura e escrita. Revista CEFAC, 11. http://dx.doi.org/10.1590/S1516-18462009005000002

Capellini, S. A., \& Lanza, S. C. (2011). Desempenho de escolares de ensino público com e sem dificuldade de aprendizagem em habilidade fonológica, Nomeação Rápida, leitura e escrita. Revista Eletrônica Acolhendo a Alfabetização nos Países de Língua Portuguesa, 1, 23-47.

Capovilla, A. G. S., Dias, N. M., \& Montiel, J. M. (2007). Desenvolvimento dos componentes da Consciência Fonológica no ensino fundamental e correlação com nota escolar. Psico-USF, 12, 55-64.

Carrilo-Mora, P. (2010). Sistemas de memória: Reseña histórica, clasificación y conceptos actuales. Salud Mental, 33, 197205.

Casella, E. B. (2009). O TDAH e transtornos de aprendizagem. Interface-TDAH e suas comorbidades. http://www.medcenter.com/Medscape/uploadedFiles/O_TDAH_e_transtornos_de_aprendizagem.pdf

Cavadas, M., Pereira, L. D., \& Mattos, P. (2007). Efeito do metilfenidato no processamento auditivo em crianças e adolescentes com Transtorno do Déficit de Atenção/Hiperatividade. Arquivos de Neuro-Psiquiatria, 65, $138-143$. http://dx.doi.org/10.1590/S0004-282X2007000100028

Chard, D. J. et al. (2008). Predicting Reading Success in a Multilevel Schoolwide Reading Model. Journal of Learning Disabilities, 41, 174-188. http://dx.doi.org/10.1177/0022219407313588

Crenitte, P. A. P. (2002). Correlação entre as manifestações de leitura/escrita e habilidades cognitivo-linguísticas em crianças com fracasso escolar. PhD Thesis, Campinas: Faculdade de Ciências Médicas, Universidade Estadual de Campinas.

Cunha, V. L. O., \& Capellini, S. A. (2009). Desempenho de escolares de $1^{\text {a }}$ a $4^{\text {a }}$ série do ensino fundamental nas provas de habilidades metafonológicas e de leitura-PROHMELE. Revista da Sociedade Brasileira de Fonoaudiologia, 14, 56-68. http://dx.doi.org/10.1590/S1516-80342009000100011

Denckla, M. B., \& Rudel, R. (1974). Rapid “Automatized” Naming of Pictured Objects, Colors, Letters and Numbers by Normal Children. Cortex, 10, 186-202. http://dx.doi.org/10.1016/S0010-9452(74)80009-2 
Diniz Neto, O., \& Sena, S. S. (2007). Distraído e a 1000 por hora: Guia para familiares, educadores e portadores de Transtorno de Déficit de Atenção/Hiperatividade (p. 104). Porto Alegre: Artmed.

Faraone, S. V. (2003). Report from the 4th International Meeting of the Attention Deficit Hyperactivity Disorder Molecular Genetics Network. American Journal of Medical Genetics Part B: Neuropsychiatric Genetics, 121B, 55-59.

http://dx.doi.org/10.1002/ajmg.b.20047

Ferreira, T. L. et al. (2003). Desempenho de escolares leitores proficientes no teste de nomeação automatizada rápida—RAN. Temas sobre Desenvolvimento, 12, 26-32.

Ferreira, T. L., Valentin, C. M. T., \& Ciasca (2013). Working Memory and Reading Development. Psychology, 4, 7-12. http://dx.doi.org/10.4236/psych.2013.410A002

Freitas, P. M., Cardoso, T. S. G., \& Siquara, G. M. (2012). Desenvolvimento da Consciência Fonológica em crianças de 4 a 8 anos de idade: Avaliação de habilidades de rima. Revista Psicopedagogia, 29, 38-45.

Gallardo-Paúls, B., \& Martinéz, M. G. (2010). Pragmática textual em adolescentes con Trastorno por Déficit de Atención/ Hiperactividad: Argumentación. Revista de Neurología, 50, 113-117.

Germano, G. D., Pinheiro, F. H., \& Capellini, S. A. (2009). Desempenho de escolares com dislexia do desenvolvimento em tarefas metalinguísticas e silábicas. Revista CEFAC, 11, 213-220. http://dx.doi.org/10.1590/S1516-18462008005000004

Gindri, G., Keske-Soares, M., \& Mota, H.B. (2007). Memória de trabalho, Consciência Fonológica e hipótese de escrita. Pró-Fono Revista de Atualização Científica, 19, 213-322. http://dx.doi.org/10.1590/s0104-56872007000300010

Gomes, M. et al. (2007). Conhecimento sobre o Transtorno de Déficit de Atenção/Hiperatividade no Brasil. The Revista Brasileira de Psiquiatria, 56, 94-101. http://dx.doi.org/10.1590/s0047-20852007000200004

González, M. R. O. et al. (2004). Evaluación de la velocidad de nombrar en las dificultades de aprendizaje de la lectura. Psicothema, 16, 442-447.

Kessler, T. M. (1997). Estudo da Memória de Trabalho em pré-escolares. Dissertação (Mestrado em Distúrbios da Comunicação Humana), São Paulo: Universidade Federal de São Paulo, Escola Paulista de Medicina.

Lobo, P. A. S., \& Lima, L. A. M. (2008). Comparação do desempenho em leitura de palavras de crianças com e sem Transtorno de Déficit de Atenção/Hiperatividade. Revista CEFAC, 10, 471-483. http://dx.doi.org/10.1590/S1516-18462008000400007

Maluf, M. R., \& Barreira, S. D. (1997). Consciência fonológica e linguagem escrita em pré-escolares. Psicologia: Reflexão e Crítica, 10. http://dx.doi.org/10.1590/S0102-79721997000100009

Martinussen, R. et al. (2005). A Meta-Analysis of Working Memory Impairments in Children with Attention-DeficitHyperactivity Disorder. Journal of the American Academy of Child \& Adolescent Psychiatry, 44, 377-384. http://dx.doi.org/10.1097/01.chi.0000153228.72591.73

Mattos, P. et al. (2006). Painel brasileiro de especilaistas sobre diagnóstico do Transtorno de Déficit de Atenção/Hiperatividade (TDAH) em adultos. Revista de Psiquiatria do Rio Grande do Sul, 28, 50-60.

Messina, L. F., \& Tiedemann, K. B. (2009). Avaliação da Memória de Trabalho em crianças com Transtorno de Déficit de Atenção e Hiperatividade. Psicologia USP, 20, 209-229. http://dx.doi.org/10.1590/S0103-65642009000200005

Miranda, A., Garcia, R., \& Jara, P. (2001). Acceso al léxico y comprensión lectora en los distintos subtipos de niños con Trastorno por Déficit de Atención com Hiperactividad. Revista Neurologia Clinica, 2, 125-138.

Miranda-Casas, A. et al. (2010). Comprensión de textos de estudiantes con Trastorno por Déficit de Atención/Hiperactividad: ¿qué papel desempeñan las funciones ejecutivas? Revista de Neurología, 50, 135-142.

Moojen, S. et al. (2003). Consciência fonológica: Instrumento de avaliação sequencial. São Paulo: Casa do Psicólogo.

Mulas, F. et al. (2006). Trastornos neuropsicológicos de los adolescentes afectos de Trastorno por Déficit de Atención con Hiperactividad. Revista de Neurología, 43, 71-81.

Nunes, C., Frota, S., \& Mousinho, R. (2009). Consciência fonológica e o processo de aprendizagem de leitura e escrita: Implicações teóricas para o embasamento da prática fonoaudiológica. Revista CEFAC, 11, 207-212. http://dx.doi.org/10.1590/S1516-18462009000200005

Oliveira, A. M. et al. (2011). Desempenho de escolares com dislexia e Transtorno de Déficit de Atenção e Hiperatividade nos processos de leitura. Revista Brasileira de Crescimento e Desenvolvimento Humano, 21, 344-355.

Oliveira, R. M. (2007). O conceito de executivo central e suas origens. Psicologia: Teoria e Pesquisa, 23, 399-406. http://dx.doi.org/10.1590/s0102-37722007000400005

Pestun, M. S. V. (2005). Consciência fonológica no início da escolarização e o desempenho ulterior em leitura e escrita: Estudo correlacional. Estudos de Psicologia (Natal), 10, 407-412. http://dx.doi.org/10.1590/S1413-294X2005000300009

Pham, A. V., Fine, J. G., \& Semrud-Clikeman, M. (2011). The Influence of Inattention and Rapid Automatized Naming on Reading Performance. Archives of Clinical Neuropsychology, 26, 214-224. http://dx.doi.org/10.1093/arclin/acr014 
Piasta, S. B., \& Wagner, R. K. (2010). Learning Letter Names and Sounds: Effects of Instruction, Letter Type, and Phonological Processing Skill. Journal of Experimental Child Psychology, 105, 324-344.

http://dx.doi.org/10.1016/j.jecp.2009.12.008

Pinheiro, F. H., Lourencetim, D., \& Santos, L. C. A. (2010). Transtorno de Déficit de Atenção e Hiperatividade: Critérios diagnósticos. In S. A. Capellini, G. D. Germano, \& V. L. O. Cunha (Eds.), Transtornos de aprendizagem e transtornos da atenção (da avaliação à intervenção) (pp. 21-33). São José dos Campos: Editora Pulso.

Pinheito, F. H., Germano, G. D., \& Capellini, S. A. (2010). A influência do treinamento auditivo para o desenvolvimento de habilidades fonológicas e silábicas em escolares com distúrbio de aprendizagem. Temas sobre Desenvolvimento, 17, 7984.

Rabiner, D. L., Malone, P. S., \& The Conduct Problems Prevention Research Group (2004). The Impact of Tutoring on Early Reading Achievement for Children with and without Attention Problems. Journal of Abnormal Child Psychology, 32, 273284. http://dx.doi.org/10.1023/B:JACP.0000026141.20174.17

Rapport, M. D., Alderson, R. M., Kofler, M. J., Sarver, D. E., Bolden, J., \& Sims, V. (2008). Working Memory Deficits in Boys with Attention-Deficit/Hyperactivity Disorder (ADHD): The Contribution of Central Executive and Subsystem Processes. Journal of Abnormal Child Psychology, 36, 825-837.

Santamaria, V. L., Leitão, P. B., \& Assencio-Ferreira, V. J. (2004). A Consciência Fonológica no processo de alfabetização. Revista CEFAC, 6, 237-241.

Schweitzer, J. B. et al. (2000). Alterations in the Functional Anatomy of Working Memory in Adult Attention Deficit Hyperactivity Disorder. The American Journal of Psychiatry, 157, 278-280. http://dx.doi.org/10.1176/appi.ajp.157.2.278

Shue, K. L., \& Douglas, V. I. (1992). Attention Deficit Hyperactivity Disorder and the Frontal Lobe Syndrome. Brain and Cognition, 20, 104-124. http://dx.doi.org/10.1016/0278-2626(92)90064-S

Silva, C., \& Capellini, S. A. (2010). Eficácia do programa de remediação fonológica e leitura no distúrbio de aprendizagem. Pró-Fono Revista de Atualização Científica, 22, 131-138. http://dx.doi.org/10.1590/s0104-56872010000200011

Silva, C., Cunha, V. L. O., \& Capellini, S. A. (2011). Desempenho cognitivo-linguistico em leitura de escolares com Transtorno de Déficit de Atenção e Hiperatividade. Revista Brasileira de Crescimento e Desenvolvimento Humano, 21, 849-858.

Sowerby, P., Seal, S., \& Tripp, G. (2011). Working Memory Deficits in ADHD: The Contribution of Age, Learning/Language Difficulties, and Task Parameters. Journal of Attention Disorders, 15, 461-472.

http://dx.doi.org/10.1177/1087054710370674

Tannock, R., Banaschewski, T., \& Gold, D. (2006). Color Naming Deficits and Attention-Deficit/Hyperactivity Disorder: A Retinal Dopaminergic Hypothesis. Behavioral and Brain Functions, 2, 4. http://dx.doi.org/10.1186/1744-9081-2-4

Van Mourik, R., Oosterlaan, J., \& Sergeant, J. A. (2005). The Stroop Revisited: A Meta-Analysis of Interference Control in AD/HD. Journal of Child Psychology and Psychiatry, 46, 150-165. http://dx.doi.org/10.1111/j.1469-7610.2004.00345.x

Villagrán, M. A. et al. (2010). Velocidad de nombrar y conciencia fonológica en el aprendizaje inicial de la lectura. Psicothema, 2, 436-42.

Voorde, S. V. et al. (2009). Working Memory, Response Inhibition, and Within-Subject Variability in Children with Attention-Deficit/Hyperactivity Disorder or Reading Disorder. Journal of Clinical and Experimental Neuropsychology, 32, 366379. http://dx.doi.org/10.1080/13803390903066865

Voorde, S. V., Roeyers, H., \& Wiersema, J. R. (2010). Error Monitoring in Children with ADHD or Reading Disorder: An Event-Related. Biological Psychology, 85, 176-185. http://dx.doi.org/10.1016/j.biopsycho.2010.01.011

Vukovic, R. K., \& Siegel, L. S. (2006). The Double-Deficit Hypothesis: A Comprehensive Analysis of the Evidence. Journal of Learning Disabilities, 39, 25-47. http://dx.doi.org/10.1177/00222194060390010401

Wagner, R. K. et al. (1997). Changing Relations between Phonological Processing Abilities and Word-Level Reading as Children Develop from Beginning to Skilled Readers: A 5-Year Longitudinal Study. Developmental Psychology, 33, 468479. http://dx.doi.org/10.1037/0012-1649.33.3.468

Wagner, R. K., \& Torgesen, J. K. (1987). The Nature of Phonological Processing and Its Causal Role in the Acquisition of Reading Skills. Psychological Bulletin, 101, 192-212. http://dx.doi.org/10.1037/0033-2909.101.2.192

Wechsler, D. (1993). Wechsler Objective Reading Dimensions. London: Pearson Assessment.

Wolf, M., \& Bowers, P. G. (1999). The Double-Deficit Hypothesis for the Developmental Dyslexias. Journal of Educational Psychology, 91, 415-438. http://dx.doi.org/10.1037/0022-0663.91.3.415

Ygual-Fernández, A. et al. (2011). Protocolo de observación del lenguaje para maestros de educación infantil. Eficacia en la detección de dificultades semânticas y morfosintácticas. Revista de Neurología, 52, 127-134.

Ygual-Fernández, A., Miranda-Casas, A., \& Cervera-Mérida, J. F. (2000). Dificultades em lãs dimensiones de forma y 
contenido del lenguaje em los niños com Trastorno por Déficit de Atención com Hiperactividad. Revista Neurologia Clinica, 1, 193-202.

Zorzi, J. L., \& Ciasca, S. M. (2009). Análise de erros ortográficos em diferentes problemas de aprendizagem. Revista CEFAC, 11, 406-416. http://dx.doi.org/10.1590/S1516-18462009000300007 